Jovan Milić

sudija Vrhovnog suda Vojvodine u penziji

Mr Mirjana Jovanović-Tomić advokat u Novom Sadu

\title{
O USTAVNOSTI I ZAKONITOSTI ODREDABA ČL. 17. STAV 3. I ČL. 18-20. ZAKONA O ODRŽAVANJU STAMBENIH ZGRADA*
}

Autori ove rasprave podneli su Saveznom ustavnom sudu inicijativu za ocenu ustavnosti i zakonitosti odredaba čl. 17. stav 3. i čl. 18-20. Zakona o održavanju stambenih zgrada (Sl. glasnik RS, br. 44/95) i proglašavanje istih suprotnim odredbama čl. 51. i 69. stav 3. i čl. 77. stav 1 . tačka 5. Ustava SRJ, čl. 18. i 19. Zakona o osnovama svojinskopravnih odnosa (Sl. list SRJ, br. 6/80, 36/90 i 29/96) i čl. 54. i 153. stav 1. Zakona o obligacionim odnosima.

Osporene odredbe Zakona o održavanju stambenih zgrada propisuju da skupština zgrade saglasnošću $51 \%$ vlasnika stanova donosi odluku o investicionom održavanju stambene zgrade (čl. 17. st. 3) i mogućnost da se na zgradama sa ravnim krovom u kojoj su stanovi u privatnoj svojini, može dozvoliti nekom od vlasnika stanova ili trećem licu izgradnja novog stana odnosno stanova i to nadogradnjom na ravnom krovu (čl. 18. st. 1. i 2).

Odluku o navedenom donosi skupština zgrade, uz mogućnost pismenog izjašnjavanja van sednice skupštine (čl. 17. st. 4) sa većinom od $51 \%$ vlasnika stambenog prostora na zgradi.

Vlasniku stana u zgradi dato je pravo da u slučaju, ako smatra da mu je odlukom skupštine zgrade povređeno neko pravo ili pravni interes zasnovan na zakonu, može tu odluku pobijati pred nadležnim sudom (čl. 20).

\footnotetext{
* Rad primljen: 23. V 2000.
} 
Citirane odredbe suprotne su čl. 69. st. 3. Ustava SRJ, čl. 18. i 19. Zakona o osnovama svojinskopravnih odnosa i Zakonu o obligacionim odnosima.

\section{Odnos osporenih odredaba Zakona prema Ustavu SRJ}

Osporene odredbe čl. 18-20. Zakona o održavanju stambenih zgrada su u suštini odredbe o orginarnom sticanju svojine izgradnjom na tuđem (zemljištu-tlu), i to svojim materijalom. Iz toga jasno proizilazi da je ovo materija saveznog zakona, saglasno čl. 77. st. 1. tač. 5. Ustava SRJ, kao odredbe o osnovama svojinskopravnih odnosa (čl. 21. i čl. 24-26. Zakona o osnovama svojinskopravnih odnosa). Ovaj stav zasniva se na sledećem:

A) To znači, pre svega, da za unošenje ovih osporenih odredaba u Republički zakon o održavanju stambenih zgrada nema ustavnog osnova, jer se radi o isključivoj nadležnosti saveznih organa. Pravo na nadziđivanje sa obavezom da se trpi izgradnja je očigledno obligacionopravni odnos graditelja sa onim na čijem se vlasništvu nadograđuje. Posle ukidanja čl. 25. ZOO koji je davao primat republičkom zakonu nad saveznim zakonom u istoj materiji, važe isključivo odredbe saveznog zakona. Iz rečenog jasno proizilazi da se ova materija - nadziđivanje nije mogla regulisati republičkim zakonom jer za takvu regulativu nema ustavnog osnova u Republičkom ustavu.

B) Osporene odredbe po svojim materijalno pravnim dejstvima bitno ugrožavaju i ograničavaju svojinska prava etažnih vlasnika na držanju, korišćenju i raspolaganju etažnim stanovima garantovanim i zajemčenim čl. 51. i 69. st. 2. Ustava SRJ, a posebno etažera na zadnjem spratu.

Članovi 51. i 69. st. 2. i 3. Ustava SRJ jemče svojinu i određuju da niko ne može biti lišen niti mu se ona može ograničiti, sem ukoliko to ne zahteva opšti interes i to uz naknadu za vlasnika na čijem se vlasništvu nadziđivanje vrši. Osporene odredbe suprotne su citiranim ustavnim odredbama, jer niti traže opšti interes niti se na njega pozivaju niti predviđaju bilo kakvu naknadu ili obezbeđenje imovinskih interesa vlasnika pogođenih nadogradnjom.

C) Dalje, polazeći od odredaba čl. 51. odnosno 69. st. 3. Ustava SRJ, sporne odredbe ne mogu biti osnov za odluku o nadziđivanju mimo saglasnosti ostalih etažera - vlasnika stanova. Saglasnost svih zajedničara u pogledu korišćenja zajedničke stvari kao princip već je sadržan u čl. 15. Zakona o osnovama svojinskopravnih odnosa. Naime, etažni vlasnici su samo vlasnici svojih etažnih stanova. O korišćenju, održavanju i raspolaganju tim stanovima kao vlasnici slobodno odlučuju. Nikakav opšti interes ne traži ovakvo ograničavanje prava svojine kako to čini navedeni zakon u pogledu etažnog vlasništva. Ograničenja koja se u ovom pogledu nameću osporavanim odredbama, tiču se ili eksproprijacije ili ustanovljenja susedskih prava ili realnih tereta. Ovde se, međutim, ne radi ni o eks- 
proprijaciji (delimičnoj), niti o stvarnim službenostima i teretima na pravu svojine vlasnika stanova nego o ograničavanju prava svojine bez zakonskog osnova.

Što se, pak, tiče zgrade kao celine, etažni vlasnici su zajedničari i kolektivno odlučuju samo u okviru poslova održavanja investicionog i tekućeg.

Pravni subjektivitet zgrade, shodno čl. 11. Zakona o održavanju stambenih zgrada, iscrpljuje se u poslovima vezanim za održavanja a koji su nabrojani u čl. 14. istog zakona. U tim poslovima nema ovlašćenja skupštini zgrade niti ovlasćenja da odlučuje o nadziđivanju i pravu zgrade da sa investitorom sklapa ugovor o nadziđivanju nad stanom odnosno stanovima u etažnom vlasništvu. Ni na koji način ne može Zakon, kao što to čini u čl. 19. osporenog zakona, da mimo propisa o ograničenju svojine, zgradi daje ovlašćenje da u svoje ime zaključuje ugovore koji se u celosti odnose na vlasnike etažnih stanova, a u svoje ime kao ugovorna strana ugovora sve obaveze iz čl. 19. osporenog zakona. Takav ugovor o obavezama etažnog vlasnika jednostavno ne obavezuje i apsolutno je ništavan. Ne može etažer biti u poziciji, u koju ga stavlja čl. 20. osporenog zakona, da on mora pobijati nezakonitu odluku skupštine zgrade.

\section{Odnos osporenih odredaba prema Zakonu o osnovama svojinskopravnih odnosa}

Kada je reč o povredama i suprotnosti osporenih odredaba Zakona o održavanju stambenih zgrada sa Zakonom o osnovama svojinskopravnih odnosa treba imati u vidu sledeće:

A) Pravni status zgrade: Zgrada je pravno lice. Delokrug njene pravne i poslovne sposobnosti dat je u čl. 11. i 12. osporenog Zakona. To su isključivi poslovi koji se odnose na održavanje i korišćenje stambene zgrade. Prema čl. 54. Zakona o obligacionim odnosima poslovna sposobnost pravnog lica kao što je i zgrada ograničena je na poslove iz čl. 11 . osporenog zakona. Prema tome, nezakonita je i suprotna zakonu odredba da zgrada kao pravno lice može sklapati ugovore iz čl. 18. stav 3. Zakona o održavanju stambenih zgrada.

Pored ove povrede, ovakvim ugovorima koji regulišu odnos između zgrade i investitora u postupku nadziđivanja, povređuju se i odredbe čl. 153. stav 1. Zakona o obligacionim odnosima: „Obećanje učinjeno drugom da će treći nešto učiniti ili propustiti, trećeg ne obavezuje..."

Prema čl. 18. stav 3: osporenog zakona ugovorne strane su isključivo zgrada i investitor. Etažer, i to u prvom redu onaj nad čijim će se stanom zidati, nije ugovorna strana a ugovor predviđa čitav niz obaveza: da se iseli i dr. i da jedino sredstvo koje mu se daje jeste tužba (čl. 20. Zakona o održavanju stambenih zgrada). Jasno je da su osporene odredbe ništave, jer bitno ograničavaju, suprotno pravilima Zakona o obliga- 
cionim odnosima, prava vlasnika (opšta dejstva ugovora - čl. 145-153. ZOB-a).

B) Naknada etažerima: Zakon o održavanju stambenih zgrada ni u jednoj svojoj odredbi ne predviđa bilo kakvu naknadu etažerima na čijim objektima svojine se zida novi objekat. Ovakvim opredeljenjem Zakona, potpuno se negira bitna komponenta prava svojine a to je da se svoja stvar ekonomski koristi. Ovo se posebno vidi iz odredaba koje regulišu eksproprijaciju i nužne prolaze. Zakon o eksproprijaciji predviđa da vlasniku nepokretnosti, koja se ekspropriše u opštem interesu pripada pravična naknada (čl. 41-45. Zakona o eksproprijaciji).

Pored toga, u slučaju konstituisanja službenosti na nepokretnosti u situacijama kada je to moguće, po Zakonu o osnovama svojinskopravnih odnosa, na zahtev vlasnika poslužnog dobra, nadležni državni organ utvrdiće i odgovarajuću naknadu koju je vlasnik povlasnog dobra dužan da plati vlasniku poslužnog dobra (čl. 53. st. 3).

Pravo građenja je imovinsko pravo. Ustupanje i priznavanje prava građenja je imovinsko pravo i ima svoju cenu (kupoprodaja građevinskog zemljišta, licitacija građevinskog zemljišta). Nerazumljivo je zašto bi nadziđivanje bilo bez naknade i to neposredno u korist onog na čijoj se ,glavi" i gradi. Zadnji etažer bi, pre svega, morao biti pitan i bez njegove saglasnosti po opštim pravilima imovinskog prava nadziđivanje nad njegovim objektom ne bi bilo moguće bez njegove saglasnosti i bez njegovog učešća u ugovoru i bez primerene naknade. Posebno je pitanje da li bi za takvu ,prodaju" bila potrebna i saglasnost zgrade kao celine jer se radi i o širem interesu svih ostalih etažera iz bezbednosnih, sigurnosnih i drugih razloga.

\section{Obezbeđenje etažera}

Posebno se postavlja pitanje obezbedenja etažera. Prema tekstu Zakona o održavanju stambenih zgrada zadnji etažer nema nikakvih sredstava obezbeđenja. U prirodi prava je da se za svako potraživanje može tražiti i davati jemstvo (zaloga, hipoteka, deponovanje).

Prilikom nadziđivanja, kada se skida krov nad stanom odnosno stanovima etažera, zakonom se moraju predvideti i određena obezbeđenja i to kako imovine tako i samih etažera. Jasno je da odsustvo takvih odredaba relativizira pravo svojine na posebnom delu zgrade (stanu) i svodi vlasništvo na stanu kao svojevrstan oblik ranijeg stanarskog prava na društvenom stanu.

\section{Uloga saveta zgrade}

Savet zgrade bi morao imati ovlašćenje da daje saglasnost na ugovore koji se zaključuju o nadziđivanju i to isključivo sa stanovišta interesa zgrade kao celine: izgled fasade, krov, instalacije i sl. 


\section{Kvorum za odlučivanje}

Rešenje Zakona da skupština zgrade donosi odluku o nadziđivanju sa $51 \%$ vlasništva nije u prirodi odnosa etažnih vlasnika stanova. Primarno i bitno je saglasnost svih etažera. Podsećamo da je ovakvo rešenje, upravo koncept rešenja, predviđao Nacrt zakona o pravu svojine SRS podnet Skupštini Srbije 03. 09. 1989. god. pod brojem 02-46-02158. Član 134. tog Nacrta predviđao je saglasnost svih etažera ili odluku suda donetu u vanparničnom postupku i to pod sledećim uslovima: da to traži većina, da je to rešenje celishodno i opravdano i da se njime ne pogoršavaju znatnije uslovi stanovanja. Pored toga, taj zakon je predviđao i ugovor etažnih vlasnika o odnosima i regulisanje odnosa u korišćenju etažnih stanova u zgradi. 